\title{
Glutamine Synthetase Activities of Cultures of Pseudomonas aeruginosa Grown in Minimal Media with Histidine, Nitrate or Ammonium Sulphate as the Nitrogen Source
}

\author{
By KERSTIN NYBERG* AND PATRICIA H. CLARKE \\ Department of Biochemistry, University College London, Gower Street, \\ London WC1E 6BT
}

(Received 23 February 1978)

\section{INTRODUCTION}

Potts \& Clarke (1976) observed that when Pseudomonas aeruginosa strain PACl was grown in minimal medium with pyruvate as carbon source and histidine as nitrogen source, there was no catabolite repression of histidase when succinate was added to the medium unless ammonium salts were added at the same time. This strain has a defective histidine uptake system and growth is nitrogen limited in minimal medium with histidine as the sole nitrogen source. Strain PACl is unable to grow on histidine alone since histidine uptake is too slow to provide carbon and energy for growth although it is able to synthesize all the enzymes required for histidine catabolism specified by the hut genes. Glucose repression of histidase in Klebsiella aerogenes does not occur in glucose/histidine medium and this has been related to the increased activity of glutamine synthetase in this medium (Prival \& Magasanik, 1971; Prival, Brenchley \& Magasanik, 1973). Glutamine synthetase activates the transcription of the hut operon in vitro (Tyler, Deleo \& Magasanik, 1974). The amount of glutamine synthetase is dependent on the nitrogen source in many bacteria and this enzyme may be essential for nitrogen assimilation when the available nitrogen, either as ammonium ions or as organic nitrogen, is present at very low concentrations (Meers, Tempest \& Brown, 1970; Magasanik et al., 1974). The histidine transport lesion of strain PACl provides a simple means of obtaining severe nitrogen limitation in a $P$. aeruginosa culture. We have investigated the glutamine synthetase activities of cultures grown in minimal medium, with the normal concentration of ammonium salts, and compared them with those of cultures grown under nitrogen limitation in histidine or nitrate medium. We have also examined cultures grown in a chemostat with growth limited by the availability of ammonium ions as the nitrogen source.

\section{METHODS}

Pseudomonas aeruginosa PAC1 (Kelly \& Clarke, 1962; strain 8602/A) was maintained on nutrient agar. Strain PAC1R is a mutant resistant to lysis by bacteriophage Ps1 which occasionally causes lysis in slowgrowing cultures. Minimal media were made up as described by Brammar \& Clarke (1964), with the carbon and nitrogen sources indicated in Table 1. Batch cultures for enzyme assays were grown in a Biotech fermenter, capacity $300 \mathrm{ml}$, until the bacterial cell density reached an $A_{670}$ of about $0 \cdot 6$. The inoculum consisted of 5 to $10 \mathrm{ml}$ of a stationary culture in the same medium. The chemostat, constructed in this department, comprised a glass vessel with an integral water jacket of $100 \mathrm{ml}$ capacity. The medium was supplied to the vessel via a Varioperpex pump (LKB); it was agitated in the course of aeration with a smallaquarium pump and also by the action of a small magnetic 'flea'. Whenever the flow rate was changed, the culture was left to stabilize for at least $24 \mathrm{~h}$. Samples of about $20 \mathrm{ml}$ were taken for enzyme assays from the culture overflow, so that the time taken to collect them varied with the dilution rate. The sample bottle was kept on ice during the collection period. The cell density $\left(A_{670}\right)$ over the range of growth rates examined was $0 \cdot 33$ to $0 \cdot 35$.

\footnotetext{
* Present address: Helsinki University of Technology, Espoo, Finland.
} 
Cultures were harvested by centrifugation and resuspended in $0 \cdot 1 \mathrm{M}$-Tris/ $\mathrm{HCl}$ buffer, $\mathrm{pH} 7 \cdot 2$. The bacteria were disrupted in a French pressure cell (Aminco) at $110 \mathrm{MPa}$ and the debris was removed by centrifugation.

Protein was determined by the method of Lowry et al. (1951). Glutamine synthetase activity was measured by the method of Shapiro \& Stadtman (1970). The exact details for this assay are important in assessing the significance of the results (Bender et al., 1977). The procedure adopted in our experiments was as follows: The assay mixture was made up to $25 \mathrm{ml}$ with $1.0 \mathrm{M}$-imidazole hydrochloride, $2.0 \mathrm{ml} ; 0.01 \mathrm{M}-\mathrm{MnCl}_{2}, 1.5 \mathrm{ml}$; $0.01 \mathrm{M}$-ADP, $1.5 \mathrm{ml} ; 0.067 \mathrm{M}$-glutamine, $15.0 \mathrm{ml} ; 1.0 \mathrm{M}$-sodium arsenate, $1.0 \mathrm{ml} ; 1.0 \mathrm{M}$-hydroxylamine hydrochloride, $1.0 \mathrm{ml} ; 1.0 \mathrm{M}-\mathrm{NaOH}, 1.0 \mathrm{ml}$; and distilled water $\left[2.0 \mathrm{M}-\mathrm{MgCl}_{2}, 1.5 \mathrm{ml}\right.$, was included for some assays]. The assay tubes contained $0.5 \mathrm{ml}$ assay mixture and $0.1 \mathrm{ml}$ (or more) enzyme preparation in $1.0 \mathrm{ml}$. Enzyme activity was linear for at least $30 \mathrm{~min}$. The standard assay was carried out with incubation at $37^{\circ} \mathrm{C}$ for $10 \mathrm{~min}$. The reaction was stopped by addition of the ferric chloride reagent described by Shapiro \& Stadtman (1970) and then $A_{540}$ was measured. Activities are expressed as $\mu$ mol $\gamma$-glutamylhydroxamate formed $\min ^{-1}$ (mg protein $)^{-1}$ in the cell extract. Glutamate synthase and glutamate dehydrogenase activities were measured by the methods of Cole et al. (1974).

\section{RESULTS AND DISCUSSION}

Growth of $P$. aeruginosa PACl in succinate/histidine or pyruvate/histidine medium was slow and the cultures became very sensitive to additional environmental stress. Some experiments were abandoned because of cell lysis which occurred more frequently when the cultures had been exposed to fluorescent light for long periods. It was found most convenient to arrange for the major period of growth to occur overnight so that the cultures could be harvested during the following morning as soon as they had reached the required cell density. With succinate/histidine and pyruvate/histidine media this took about $20 \mathrm{~h}( \pm 2 \mathrm{~h})$. For some experiments strain PAC1R was used; this had a slightly faster growth rate in these media, reaching the required cell density in about $16 \mathrm{~h}$ or less. (This may mean that the resistance to bacteriophage Ps1 is associated with a surface change which also has the effect of allowing it to take up histidine slightly better than the parent strain.) The cultures grown with nitrate took about 10 to $12 \mathrm{~h}$ to reach a cell density equivalent of $0 \cdot 6$. The cultures growing in the $\mathrm{NH}_{4}{ }^{+}$media took 5 to $7 \mathrm{~h}$ and were in the exponential growth phase, whereas growth of the histidine and nitrate cultures was almost linear.

Cultures grown in the fermenter in minimal media with histidine or nitrate as nitrogen source had higher glutamine synthetase activities than those grown with $10 \mathrm{mM}-\left(\mathrm{NH}_{4}\right)_{2} \mathrm{SO}_{4}$ (Table 1). This had been expected and was consistent with the presumed role of glutamine synthetase in the relief of succinate repression of histidase synthesis in nitrogen-limited medium. [We were concerned about the variation between separate experiments under the same growth conditions, a problem which has been encountered by other workers studying glutamine synthetase in the enterobacteria (Brenchley, Baker \& Patil, 1975; Bender et al., 1977). We have therefore given the results of single experiments rather than the mean of a series. All assays were carried out in duplicate and the results were reproducible for each preparation within, at most, $\pm 5 \%$.] Also included in Table 1 are the results from experiments with strain PAClR grown in the fermenter and PACl grown in conical flasks on a shaker. The flask cultures of PACl growing in succinate/histidine medium were less susceptible to spontaneous lysis than those growing in the fermenter.

The total glutamine synthetase activities of PACl cultures grown in $\mathrm{NH}_{4}{ }^{+}$media, and for PACl grown in the succinate/histidine medium in a shaken flask, are within the range reported for enterobacteria grown in nitrogen-excess and nitrogen-limited media: Bloom, Streicher \& Tyler (1977) reported values of $0 \cdot 22$ and $1 \cdot 29$, respectively, for Klebsiella aerogenes and $0 \cdot 10$ and 1.45 for Salmonella typhimurium. These results, with about 10 -fold differences, are similar to those reported by other workers using a variety of methods to obtain nitrogenlimited growth. We had previously found little difference in total glutamine synthetase activities of flask cultures of strains PACl or PAClR grown with concentrations of $\left(\mathrm{NH}_{4}\right)_{2} \mathrm{SO}_{4}$ ranging from 1 to $100 \mathrm{~mm}$ but invariably found activities about 10-fold higher in cultures grown in succinate/histidine medium. 
Table 1. The effect of the nitrogen source on glutamine synthetase activities of Pseudomonas aeruginosa

Cultures were grown in minimal medium with the carbon $(1 \%, \mathrm{w} / \mathrm{v})$ and nitrogen $(10 \mathrm{~mm})$ sources indicated. Glutamine synthetase activities were measured in cell extracts and are expressed as $\mu$ mol $\gamma$-glutamylhydroxamate formed $\min ^{-1}(\text { mg protein })^{-1}$.

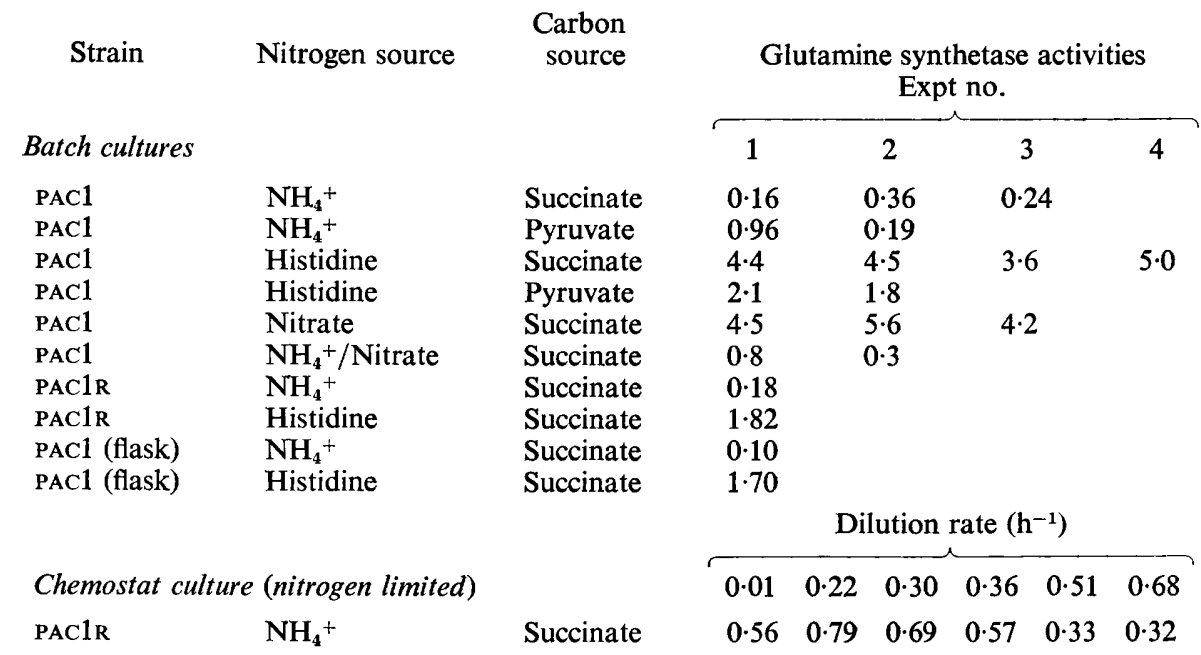

Glutamine synthetase activities of PAC1 grown in succinate/histidine medium in the fermenter were significantly higher than those obtained in flask culture. The nitrogen limitation of the PACl cultures in the succinate/histidine medium was severe, as evidenced by the low growth rate, and under these conditions the glutamine synthetase may be completely derepressed. The activities of the succinate/histidine cultures were about twice those of the pyruvate/histidine cultures. In minimal salt media with $0.1 \%\left(\mathrm{NH}_{4}\right)_{2} \mathrm{SO}_{4}$, succinate can support a doubling time of about $50 \mathrm{~min}$ at $37^{\circ} \mathrm{C}$ and pyruvate about $90 \mathrm{~min}$. This may mean that the internal pool of available nitrogen in the succinate/histidine cultures is lower than that in the pyruvate/histidine cultures and allows greater derepression of glutamine synthetase.

The chemostat cultures were limited by the $\mathrm{NH}_{4}{ }^{+}$supply, but this did not lead to particularly elevated levels of glutamine synthetase, a result which was consistent with the inability to obtain elevated levels of glutamine synthetase in batch culture with low concentrations of $\left(\mathrm{NH}_{4}\right)_{2} \mathrm{SO}_{4}$. However, there were significant variations over the growth rates studied with a maximum at a dilution rate of $0.25 \mathrm{~h}^{-1}$. Variations have also been observed in glutamine synthetase activities of Pseudomonas putida in chemostat culture over a range of dilution rates with growth limited by the $\mathrm{NH}_{4}{ }^{+}$concentration (P. D. Laverack, personal communication).

Glutamine synthetase is regulated in activity by reversible adenylylation (Stadtman et al., 1970). The assay developed for measuring the state of adenylylation of the Escherichia coli enzyme depended on the observation that the standard assay in the presence of $\mathrm{Mn}^{2+}$ measured the total activity and the assay in the presence of $\mathrm{Mn}^{2+}$ and $\mathrm{Mg}^{2+}$ measured only the biosynthetically active, non-adenylylated form. The assay procedure was complicated by the finding that activities of the non-adenylylated and adenylylated species varied with $\mathrm{pH}$ but not to the same extent. It was also observed that the non-adenylylated form might be activated by $\mathrm{Mg}^{2+}$. Recently, Bender et al. (1977) have re-examined the glutamine synthetase of $K$. aerogenes and point out that it differs from that of $E$. coli in several respects. An important finding was that the $\mathrm{pH}$ isoactivity point of the two forms of the $K$. aerogenes enzyme was quite different from that of the E. coli enzyme and that it was altered by 
changes in the components of the reaction mixture. They also observed that the apparent glutamine synthetase activities changed during harvesting of the cultures. Previously, Brenchley et al. (1975) had reported that the glutamine synthetase from cells of $K$. aerogenes and $S$. typhimurium harvested in exponential growth phase was non-adenylylated, irrespective of whether they were grown with nitrogen-excess or nitrogen-limitation. These workers found little or no difference in assays in the presence and absence of $\mathrm{Mg}^{2+}$ with extracts from the exponentially growing cells, although with the stationary phase cells there were marked differences in the presumed state of adenylylation.

Tronick, Ciardi \& Stadtman (1973) reported that $P$. aeruginosa grown in minimal media with high and low concentrations of $\mathrm{NH}_{4}{ }^{+}$showed differences in the adenylylation state of glutamine synthetase, and we hoped that these differences would be apparent in our experiments. All the assays listed in Table 1 were also carried out in the presence of $\mathrm{Mg}^{2+}$ but we have not included the values obtained since we are uncertain of the significance that should be attached to them. There were only slight differences in glutamine synthetase activities measured in the presence or absence of $\mathrm{Mg}^{2+}$ over the $\mathrm{pH}$ range 6.8 to 7.5 so that although an isoactivity point had not been established it seemed reasonable to make comparisons using the standard assay conditions at $\mathrm{pH} 7 \cdot 1$. All the extracts from the fermenter cultures grown in histidine-limiting medium had much lower activities (about a third) in the presence of $\mathrm{Mg}^{2+}$ and this could mean that most of the glutamine synthetase was adenylylated. The glutamine synthetase activities of the cultures grown with $\mathrm{NH}_{4}{ }^{+}$ were also somewhat lower in the presence of $\mathrm{Mg}^{2+}$ in most cases. On the other hand, our previous series of experiments in which strain PACl had been grown in histidine medium in shaken flasks had shown that the glutamine synthetase activities of the nitrogen-limited cultures were higher in the presence of $\mathrm{Mg}^{2+}$, i.e. the non-adenylylated activity was greater than the 'total' activity. Bender et al. (1977) have shown that at some $\mathrm{pH}$ values the nonadenylyated form of glutamine synthetase of $K$. aerogenes is markedly activated by $\mathrm{Mg}^{2+}$ and we suspect that this is also true for the enzyme from $P$. aeruginosa. Activation by $\mathrm{Mg}^{2+}$ was most apparent in our experiments with the extracts prepared from chemostat cultures where the glutamine synthetase activities doubled in the presence of $\mathrm{Mg}^{2+}$. Newman \& Cole (1977) observed $\mathrm{Mg}^{2+}$ stimulation of glutamine synthetase in nitrogen-limited chemostat cultures of $E$. coli.

The discrepancies in the $\mathrm{Mg}^{2+}$ effects on glutamine synthetase activities of $P$. aeruginosa grown under various conditions in nitrogen-excess and nitrogen-limited media are similar to those discussed by Bender et al. (1977) for $K$. aerogenes and we feel unable to reach conclusions on the adenylylation states of the $P$. aeruginosa enzyme without further study. The main problems appear to be (i) the adenylylation state may change during harvesting and the extent to which this happens may depend on the medium on which the culture has been grown, (ii) $\mathrm{Mg}^{2+}$ may activate one form and inhibit the other and (iii) there may be differences in the $\mathrm{pH}$ isoactivity points and these may vary with the other components of the assay mixture.

In some of the experiments reported in Table 1 the activities of glutamate dehydrogenase and glutamate synthase were also measured. The variations in glutamate synthase were not significant but the glutamate dehydrogenase activities of the succinate/ $\mathrm{NH}_{4}{ }^{+}$culture were 10-fold higher than those for the succinate/histidine and succinate/nitrate cultures $[0 \cdot 70$, 0.05 and $0.07 \mu \mathrm{mol} \mathrm{NADH}$ oxidized $\mathrm{min}^{-1}$ (mg protein) ${ }^{-1}$, respectively].

We conclude that the total amount of glutamine synthetase produced by $P$. aeruginosa varies inversely with the available nitrogen and that it is probably important in nitrogen assimilation. The correlation of high glutamine synthetase activities and relief from catabolite repression in minimal media with histidine as the growth-limiting nitrogen source suggests that glutamine synthetase plays an active role in the regulation of the hut genes of $P$. aeruginosa. 
We are grateful to P. D. Laverack who ran the chemostat cultures and assisted with some of the assays. K.N. is grateful to the Royal Society and to Suomen Kulttuurirahasto, Finland, for support during this investigation.

\section{REFERENCES}

Bender, R. A., JANSSEN, K. A., Resnick, A. D., Blumenberg, M., Foor, F. \& Magasanik, B. (1977). Biochemical parameters of glutamine synthetase from Klebsiella aerogenes. Journal of Bacteriology 129, 1001-1009.

Bloom, F. R., Streicher, S. L. \& Tyler, B. (1977). Regulation of enzyme synthesis by the glutamine synthetase of Salmonella typhimurium; a factor in addition to glutamine synthetase is required for activation of enzyme formation. Journal of Bacteriology 130, 983-990.

Brammar, W. J. \& Clarke, P. H. (1964). Induction and repression of Pseudomonas aeruginosa amidase. Journal of General Microbiology 37, 307-319.

Brenchley, J. E., Baker, C. A. \& Patil, L. G. (1975). Regulation of the ammonia assimilatory enzymes in Salmonella typhimurium. Journal of Bacteriology 124, 182-189.

Cole, J. A., Coleman, K. J., Compton, B. E., Kavanagh, B. M. \& Keevil, C. W. (1974). Nitrite and ammonia assimilation by anaerobic continuous cultures of Escherichia coli. Journal of General Microbiology 85, 11-22.

Kelly, M. \& Clarke, P. H. (1962). An inducible amidase produced by a strain of Pseudomonas aeruginosa. Journal of General Microbiology 27, 305-316.

Lowry, O. H., Rosebrough, N. J., Farr, A. L. \& RANDALL, R. J. (1951). Protein measurement with the Folin phenol reagent. Journal of Biological Chemistry 193, 265-275.

Magasanik, B., Prival, M. J., Brenchley, J. E., Tyler, B. M., Deleo, A. B., Streicher, S. L., Bender, R. A. \& Paris, C. G. (1974). Glutamine synthetase as a regulator of enzyme synthesis. Current Topics in Cellular Regulation 8, 119-138.

Meers, J. L., Tempest, D. W. \& Brown, C. M. (1970). 'Glutamine(amide):2-oxoglutarate amino transferase oxido-reductase (NADP)', an enzyme involved in the synthesis of glutamate by some bacteria. Journal of General Microbiology 64, 187-194.

Newman, B. M. \& Cole, J. A. (1977). Lack of a regulatory function for glutamine synthetase protein in the synthesis of glutamate dehydrogenase and nitrite reductase in Escherichia coli K12. Journal of General Microbiology 98, 369-377.

PotTs, J. R. \& Clarke, P. H. (1976). The effect of nitrogen limitation on catabolite repression of amidase, histidase and urocanase in Pseudomonas aeruginosa. Journal of General Microbiology 93, 377-387.

Prival, M. \& Magasanik, B. (1971). Resistance to catabolite repression of histidase and proline oxidase during nitrogen limited growth of Klebsiella aerogenes. Journal of Biological Chemistry 246, 6288-6296.

Prival, M., Brenchley, J. \& Magasanik, B. (1973). Glutamine synthetase and the regulation of histidase formation in Klebsiella aerogenes. Journal of Biological Chemistry 248, 4334-4344.

Shapiro, B. M. \& Stadtman, E. R. (1970). Glutamine synthetase (E. coli). Methods in Enzymology 17A, 910-922.

Stadtman, E. R., Ginsburg, A., Ciardi, J. E., Yeh, J., Hennig, S. B. \& Shapiro, B. M. (1970). Multiple molecular forms of glutamine synthetase produced by enzyme catalyzed adenylylation and deadenylylation reactions. Advances in Enzyme Regulation 8, 99-118.

Tronick, S. R., Ciardi, J. E. \& Stadtman, E. R. (1973). Comparative biochemical and immunological studies of bacterial glutamine synthetases. Journal of Bacteriology 115, 858-868.

Tyler, B. M., Deleo, A. B. \& MagasaniK, B. (1974). Activation of transcription of hut DNA by glutamine synthetase. Proceedings of the National Academy of Sciences of the United States of America 71, 225-229. 